Article

\title{
The Relative Role of the Intellectual and Moral Virtues in Sustainable Management Decisions: The Case of Practical Wisdom and Justice
}

\author{
Natàlia Cugueró-Escofet ${ }^{1, *(1)}$ and Josep M. Rosanas ${ }^{2}$ \\ 1 Faculty of Economics and Business Studies, Universitat Oberta de Catalunya, Rambla del Poblenou, 156, \\ 08018 Barcelona, Spain \\ 2 IESE Business School, Universidad de Navarra, Avinguda Pearson, 2108034 Barcelona, Spain; \\ jrosanas@iese.edu \\ * Correspondence: ncuguero@uoc.edu; Tel.: +34-932-535-791
}

Received: 21 December 2019; Accepted: 27 January 2020; Published: 6 February 2020

\begin{abstract}
We analyze the status of virtues in management by going in some depth into the two main virtues, justice and practical wisdom. We next study how ethics requires that all virtues should be present under the ideal concept of a 'unity of virtues' for a completely wise person and discuss the practical limitations of this concept. Then, we draw a framework for decision making depending on whether the decision maker possesses justice and practical wisdom or lacks one of them and then discuss which one is better to have. We conclude that justice is more important, as it is about setting objectives and prioritizing, whereas practical wisdom is about attaining these objectives, once listed, in a rationally wise and contextual way. Hence, we conclude that objectives (justice) must come first, because this makes it more likely that, in the end, practical wisdom is developed, and thus we end up having the two virtues.
\end{abstract}

Keywords: Justice; Fairness; Virtue ethics; Practical wisdom

\section{Introduction}

Business ethics has become one of the important fields in management in the last few decades. The two most important journals specializing in the subject have relatively recent origins: the Journal of Business Ethics first appeared in 1982, and Business Ethics Quarterly in 1991. A large percentage of their content, however, has been devoted to environmental issues, corporate social responsibility, and so on. Only a fraction of these journals and others has been devoted to virtue ethics, and only a fraction of these analyze some of the classical virtues, like justice or practical wisdom. Specifically, of the 441 articles published in the Journal of Business Ethics in 2018, only seven analyze virtues in some depth, and eight additional articles include the word 'virtues', even if it appears in a way that is not substantial but rather spurious (i.e., just characterizing some aspects about them). In Business Ethics Quarterly, the total number of papers published in 2018 was 47; of these only one paper analyzes virtues in some depth, while two additional papers include virtues but in the context of a much lighter type of analysis.

Virtues have been studied in many fields, essentially based on Aristotle as the first author to systematically analyzed them in order to generate a meaningful purpose in life. The idea of flourishing [1] has been lately developed in management by researchers that consider this concept as the crucial objective that is worthy of pursuit [2]. Also, recent scholars have considered that virtues are embedded in all predominant theories (e.g., utilitarianism and Kantianism) and are better discussed based on a specific author and framework because what matters is the substantial view each thinker 
has [3]. This is the main reason for choosing Aristotle's framework of intellectual and moral virtues and the two main virtues associated with intellectual and moral spheres-practical wisdom and justice.

Trying to improve the relationship between ethics and science, Appiah recognizes that, in psychology, it is usually argued that evaluative judgments are considered not to depend on facts. In contrast, he argues, "our evaluative and non-evaluative judgments must cohere in a way that makes it rational sometimes to abandon even what looks like a basic evaluative judgment because we have changed our minds about the facts" [4]. This means that, in fact, we always adjust our basic evaluative judgments in the light of the scientific understanding we have regarding a given matter. This aligns with the Aristotelian intellectual virtue of practical wisdom, updated for a specific situation. Hence, sometimes, the course of action selected may not lead to the end considered to be good (guided by the moral criteria of justice), therefore, people update their knowledge looking at the facts or results. This line of thinking, that facts feed evaluative and non-evaluative learning, is also consistent with the reconciliation and necessary inputs coming from moral justice, which cannot be separated from the ones coming from justice perceptions, as some research on organizational justice claims [5]. Another current approach in management suggests that the personal and professional domains cannot be separated-what we learn in one of them is applied to the other irremediably, which implies that the person integrates the development of virtues and translates it into every sphere of life. Therefore, we need to be consistent and apply virtues in a more integrated vein [6].

Psychological approaches have also improved our understanding of the role of virtues into the decision-making process, proposing psychological models that have evolved over time and have put forward the underlying mechanisms regarding how ethical decisions are taken from a person-centric perspective, as is the case of Ethical Decision-Making Theory (EDMT) [7,8]. EDMT integrates work from moral development perspectives by Rest [9] and the person-situation analyzes developed by Treviño, Weavor, and Reynolds, in which the contextual variables are regarded as very important [10-14] and in which the introduction of situational knowledge can be considered close to Aristotelian practical wisdom. However, interest in virtues has been increasing over time: these two ethical virtues have received more and more attention in the management literature in recent years.

Practical wisdom or "phronēsis" (the original Greek word) is an Aristotelian concept that has been incorporated into management research to a considerable extent over the last 30 years. While 30 years ago it may have been considered 'the forgotten virtue', it is not anymore [15]. Phronēsis has been studied in the field of strategy [16], in organization [17], in learning [18], from a general perspective [19], from the perspective of management education [20], and even from a practical point of view as the cornerstone of a possible new management 'Renaissance' [21]. Virtues from an individual managerial perspective are not detached from organizational virtuousness, as "virtuousness is associated with what individuals and organizations aspire to be when they are at their very best" ([22], p. 3). Therefore, theories of Positive Organizational Behavior have also considered that organizations that engage in virtuousness promote a meaningful purpose in life [23] and personal flourishing [24].

Justice has also received attention, and the field of 'Organizational Justice' has been prospering perhaps even more, as many reviews of the field suggest $[25,26]$, mainly concentrated in the area of organizational behavior but also receiving more attention in boundary areas, like ethics and management control systems, in the last couple of decades [27]. Organizational justice measures the perception of fairness from four different aspects of justice (distribution, procedure, information, and interpersonal treatment). Measured this way, injustice has been considered a predictor of many counterproductive behaviors [28], and from a managerial perspective, some research shows that the need to manage justice perceptions is part of the managerial endeavor [29]. Recent work has added additional dimensions to justice perceptions, like empathy, for instance, or having considerations about personal circumstances [30]. Besides, recent models in Sustainable Human Resource Management have considered organizational justice as one of the main variables explaining knowledgesharing behaviors in organizations [31]. From a more philosophical perspective, business ethics has approached justice as a virtue attached to business relationships that should be learnt and practiced [5] and also as formal 
and informal requirements of management control systems to generate goal congruence behaviors and long-term fairness perceptions [32].

Interestingly, the relationship between practical wisdom (the main intellectual virtue) and justice (the main moral virtue) has not been studied in depth. Whether one is more important than the other, and hence whether one of these two virtues should be prioritized over the other in case of conflict, is an intriguing question that we intend to answer in this paper. Notice that practical wisdom is an intellectual virtue, while justice is a moral virtue, and thus, the relationship between them is not trivial, making it necessary to understand the difference between the two and their moral and intellectual categorization.

We start by analyzing the status of ethics in management and the different attitudes toward it. Next, we go in some depth into the two main virtues of justice and practical wisdom, the ones that in management have been considered the two most relevant. We then analyze how ethics has looked into the inclusion of virtues under the concept 'unity of virtues' as an ideal of a completely wise person. 'Unity of virtues' means that it is only possible to be virtuous by having a character with all the virtues altogether: if someone lacks one virtue, they are not virtuous, as all virtues must be present at once. We explain that this concept has some limitations in reality, as one can easily find people that are considered virtuous for having strongly developed one of the main virtues while lacking (or simply having developed less) one of the remaining important virtues. We also provide some examples of this. We continue proposing weak unity of virtues for managers with the inclusion of both justice and practical wisdom as the two main virtues that a manager would need to practice decision making that is wise.

However, as both virtues are difficult to develop, we propose the study of justice and practical wisdom together with the assumption that it is somehow difficult to have both virtues at the same time initially, thus arguing how both virtues combine to generate four states of managerial decision making, in case of having or not having justice and practical wisdom. We consider that it is more realistic to give preference to one virtue and then develop the other, and we try to discuss which of the two is preferable in the short run. For this, we develop a framework of decision making depending on whether justice and practical wisdom are displayed or not by managers. We consider that justice is more important because it is about setting objectives and prioritizing, whereas practical wisdom is about attaining these objectives, once set, in a rationally wise and contextual way. Therefore, we conclude by stating that when objectives (justice) are set first, this makes it more probable that, in the end, both virtues - justice and practical wisdom — end up being present and developed in the long run. We argue that sustainable management should give preference to justice over practical wisdom because doing so eases the creation of dynamics toward wiser management. Thus, managers should be aware of this to improve and become wiser over time. We discuss this from the perspective of the manager at the individual level, even if organizational and individual levels are correlated and management that display virtues generate an organization that incorporates virtuousness at the organizational level [33].

\section{Management and Ethics}

Business Ethics as an academic discipline has continued in the last few decades. This has coincided with (or perhaps is a consequence of) the successive waves of big scandals: Bausch and Lomb in the 1990s; ENRON, Tyco, Worldcom, and Parmalat at the beginning of the 21st century; and Lehman Brothers, Bear Sterns, Madoff, and many more since the beginning of the Great Recession. These scandals have been enough to foster the interest in ethics. According to Ghoshal, what business schools teach has a direct relationship with those scandals, and, therefore, they should stop teaching much of what they currently teach: "Many of the worst excesses of recent management practices have their roots in a set of ideas that have emerged from business schools academics over the last 30 years" [34].

This set of ideas to which Ghoshal refers comes both in economics and in management from a school of thought that claims that ethics does not have any role to play in these disciplines. In economics, an often-quoted Friedman article (1970) states that the only social responsibility of the firm 
is to make profits. Of course, within the legal context, and according to Jensen [35] in an "enlightened" way, this means being able to see beyond the immediate possible gains in order to maximize profits in the long run or (in Jensen's terms) the firm's value, which is conceptually superior to just profit maximizing or maximizing shareholder's value [35].

On the management side, Pfeffer [36] has been very critical of the ethical view. He argues against what he calls "leadership BS" that is often preached in books and articles about leadership, because what most 'successful' leaders do is the complete reverse of what is demanded of them in the academic literature. According to Pfeffer, this is based on 'morality' and having a good relationship with co-workers/employees. In contrast, what real-world leaders actually do is often immoral. This attitude has been (perhaps implicitly) relatively common among economics and management researchers.

More practically oriented management researchers, and many practitioners, claim that the basic criterion for decision making should be effectiveness. Effectiveness is reflected mainly in the accounting numbers and perhaps in other highly visible variables (balanced scorecards, KPIs, and so on), which often leads to the concept of simply maximizing shareholder's value. That is what "most CEOs and Boards believe their main duty is, but it is not" [37]. Interestingly, companies still insist on this being the case after Jensen has shown that this last variable is technically wrong because it does not consider risk. According to him, they should attempt to maximize (enlightened) firm value instead [35].

Finally, Jensen, like Pfeffer and many other academicians, prefers to avoid 'value judgments-i.e., assessing whether something is good or bad-because value judgments are considered 'unscientific'. Jensen, instead, has developed the idea of 'integrity', which according to him is not ethics but a 'positive' concept [38]. More or less explicitly, the idea behind this is that Pfeffer's approach is a 'realistic' approach, while 'BS' analyzes are not: managers should base their decisions on facts instead of values. Furthermore, even if some research has recognized that shareholder value maximization is not the main duty of leaders [37], many big companies still have shareholder value as a core practice of leadership and publicly display it in their mission statements (see, for example, https://www.missionstatements.com/fortune_500_mission_statements.html).

Virtues are considered crucial in management from different fronts. Virtue ethics has considered that the main duty for managers is to improve decision making by being virtuous and displaying virtues through example. The two main virtues studied in management are justice and practical wisdom. From different points of view, we are going to examine next the main concepts studied in management regarding these two virtues

\section{Practical Wisdom as the Main Intellectual Virtue and Justice as the Main Moral Virtue}

Aristotle distinguished between moral virtues and intellectual virtues. Interestingly, while the chief intellectual virtues (five) are enumerated and commented one by one (with no intention of exhaustiveness), he gives only some examples of moral virtues. All of them are based on the principle of the golden mean, stressing the ones he must have considered the most important: first, justice, to which he entirely devotes Book V, and afterward, temperance and courage (included in Book IV with other virtues, but in separate sections).

\subsection{Practical Wisdom}

Among the intellectual virtues, and even with further reason in the context of management, one of them appears to be particularly important: practical wisdom (phronēsis). Aristotle considered practical wisdom an intellectual virtue: "Virtue too is distinguished into kinds in accordance with this difference; for we say that some of the virtues are intellectual and others moral, philosophic wisdom and understanding and practical wisdom being intellectual, liberality and temperance moral" ([1], Book I, 1130a).

Practical wisdom is difficult to define and to grasp, but the idea that (philosophical) wisdom alone is never enough is typically clear in the mind of real-world decision-makers. Aristotle, conscious of this difficulty, attempts to define it through the people who have it: 
"Regarding practical wisdom we shall get at the truth by considering who are the persons we credit with it. Now it is thought to be a mark of a man of practical wisdom to be able to deliberate well about what is good and expedient for himself, not in some particular respect, e.g., about what sorts of thing conduce to health or to strength, but about what sorts of thing conduce to the good life in general.

This is shown by the fact that we credit men with practical wisdom in some particular respect when they have calculated well with a view to some good end which is one of those that are not the object of any art. It follows that in the general sense also the man who is capable of deliberating has practical wisdom. Now no one deliberates about things that are invariable, or about things that it is impossible for him to do. Therefore, since scientific knowledge involves demonstration, but there is no demonstration of things whose first principles are variable (for all such things might actually be otherwise), and since it is impossible to deliberate about things that are of necessity, practical wisdom cannot be scientific knowledge or art; not science because that which can be done is capable of being otherwise, not art because action and making are different kinds of thing" ([1], Book VI, 1140a-1140b).

In other words, practical wisdom goes beyond philosophical wisdom, which is the union of intuitive reason (nous), in the Aristotelian language, and the formal apparatus of science (episteme). Intuitive reason can be thought to be the principles (axioms) that one can find in any formally structured science, which must come directly from observation; requiring them to come from demonstration would simply imply an infinite regress.

Practical wisdom is particularly important in management [39]. Actually, it is important for any practical purpose, but its relative importance depends on the specific problem we have in mind. Whenever someone is involved in a complex engineering work (say, putting a satellite in orbit), some practical wisdom is needed, but if it could possibly be done by one person alone, what has to be done is 'almost' determined by the science of physics. In contrast, in management, if what has to be done is, say, a re-structuring of an organization, some scientific notions will be undoubtedly useful, but practical wisdom is crucial, because science alone falls very short of the objective one might have in mind-not to mention the fact that practical wisdom has to be present from the beginning in the 'deliberations' about whether restructuring the organization leads to an end that is a good. However, and quite obviously, when putting a satellite in orbit, we have to build a human organization, and practical wisdom is essential.

\subsection{Justice}

According to Aristotle, justice is the greatest of the moral virtues and, in it, every virtue is comprehended ([1], Book V). It is a virtue crucial in organizations, and a full area of research labeled 'Organizational Justice' has been developing it, which is concerned with the perceptions of fairness from the recipients of the decisions. In this area, it is concluded that, when justice is not managed, there is the generation of undesired and counterproductive consequences [5]. Justice has been studied theoretically and empirically in the field of business ethics, and in general management, managerial accounting and human resource management. Justice is the virtue that assists decision makers on how to establish what is right between parties and how to prioritize between objectives and resources (both tangible and intangible). Recent research suggests that justice can be considered as a provision of the system, as an aspect concerning the decision maker (acting justice), and as consequence of the decision, so attached to the perception $[40,41]$.

Distinctions between substantive and perceptional justice have also been crucial, as "perceptions may show a picture of reality or possible ways of improvement, but ethical justice reasoning needs to set limits on the way those perceptions are to be managed, and may suggest even more radical ways of improvement by departing from the observable" ([5], p. 447).

In organizational management control systems, ex ante justice has a formal dimension, which concerns the formal provisions of the system in terms of justice, and an informal dimension, which concerns managerial applications that follow some sort of formal justice standard, value, or norm. The design and use of a management control system need to take into account both types of justice 
to ensure the long-term alignment between the interests of the organization and its people [32]. The existence of ex ante formal and informal justice and the alignment of interests would enhance the fairness perceptions of those affected by decisions [42,43]. Justice has been considered important in organizations, as part of the informal systems that allow us to overcome the potential dysfunctional effects in terms of rewarding people in organizations [27]. Fairness perceptions are crucial, as perceived unfairness can result in significantly dysfunctional ex post behavior [44-46]. Both types of justice have been seen to be important, formal (regarding the formalities and rules of the system) and informal (regarding how managers decide using the systems and in specific situations), informal justice being a sufficient condition to end up generating both types of justice in the end [47].

\subsection{Justice and Practical Wisdom Together}

The relationship between justice and practical wisdom has not been studied in a direct way. Indirectly, some research has considered that they may have some relationship. To illustrate, in order to be practically wise, one needs first to choose the right or just objectives, which means that justice is shown at some point as more important, as it refers to the ends that are desirable to be morally pursued. It is difficult to conceive of someone being wise if that person is unjust, while acquiring practical wisdom is a process of knowledge gaining that requires improvement over time.

To acquire practical wisdom, the judgment of what is at stake from the perspective of the relevant parties is required. Therefore, choosing the just outcome seems a requirement to find adequate (practically wise) ways to achieve it. Therefore, a person needs "the capacity to judge what is at stake and what is at stake from the perspective of the relevant parties" ([48], p. 285).

Aristotle considers that justice is the greatest of all virtues and that this reflection involves judging and balancing the perceptions of reality with our normative frameworks and updating these frameworks if there are relevant reasons to do so [5]. Learning how to manage means learning how to be just, because people update their perceptions of justice as they look at managers and companies with respect to how able these are when it comes to creating justice.

On the other hand, practical wisdom is concerned mainly with the means. Therefore, we need practical wisdom concerned with the "habit of mind whereby one is excellent in each case at finding the available means to accomplish a worthy end" ([49], p. 427). It is precisely justice what informs this worthy end.

\section{Unity of Virtues and Direct Observation Against It}

Taking into account only two of the virtues seems to go against the principle of the unity of the virtues, which Aristotle, like many other classical Greek philosophers, clearly adhere to. They seem to imply that a virtuous person should possess all the virtues at once. Aristotle attempts to refute the idea that virtues can "exist in separation from each other"; however, "the same man, it might be said, is not best equipped by nature for all the virtues, so that he will have already acquired one when he has not yet acquired another. This is possible in respect of the natural virtues, but not in respect of those in respect of which a man is called without qualification good" [50]. Nevertheless, direct observation appears to contradict this idea, for it can be seen easily that virtues may function separately from each other. That is, a person may be courageous but dishonest, or may be just but lazy.

In general there are alternative proposals to the unity of virtues thesis, depending on whether the proponents argue for a unity of virtues in a stronger or in a weaker sense [50]. Wolf states that we can consider virtues weakly united in terms of the knowledge involved-that is, "the kind of knowledge that is required for the virtues, on this conception, is knowledge of what's important, knowledge of what matters. A person who has this kind of knowledge we may describe as 'having her priorities straight'. As the reference to 'priorities' suggests, however, such knowledge of value seems to be essentially unified" ([50], p. 14).

Therefore, this knowledge unifies virtues weakly in the sense that it is necessary in order to develop all moral virtues. Again, according to Wolf, there are two premises. First, that each virtue 
essentially involves knowledge; in particular, knowledge of what is important. Second, that knowledge is essentially unified - that is, the perfect and complete knowledge of the importance of one item requires knowledge of the importance of everything else against which it may, in principle, need to be balanced. Therefore, in this sense, virtue is unified.

Then, to understand the virtues' unity or lack thereof, it seems essential to understand which knowledge is important and how this knowledge is related to virtues and the process by which human beings acquire them. All virtues could affect all professions, so there is no clear direct link between a profession and a virtue. There are many professions which allow a person to live a virtuous life, but this is perfectly compatible with the view that acquiring some specific virtues could be more crucial in one profession than in another-specifically in the so-called natural dispositions that people have from their childhood [50].

Here, we are concerned with the management profession, so we focus the discussion as much as possible on managers, their decisions, their acts and the virtues that affect them. We are also concerned with realistic empirical evidence of finding situations where virtues may not all be attainable in the short run at the same time, so there is room for considering that a virtuous person can start by focusing more on one virtue and then acquiring the others. Practical wisdom is the type of knowledge involved in this process of acquisition, "for with the presence of one quality, practical wisdom, will be given all the virtues" ([1], Book VI). Aristotle, however, does not say how practical wisdom intervenes in the specific process of acquisition that we set out here. We also try to show all the other types of knowledge involved and how they intervene in and develop what we think is a virtuous manager.

Of course, it is reasonable to agree that the ideal is to possess all virtues at once (a perfect state of affairs, in which we embrace all the virtues and each reinforces the other), but as we mentioned before, this may not happen in reality. The examples cited in Wolf (2007) of Patton, Clinton, Mother Theresa, and Gandhi show a more realistic picture. We can, along similar lines, find situations in business where one has to choose which one of the virtues should be dominant in the short term. This is a more reasonable and realistic approach, which goes beyond Wolf's analysis.

\section{The Unity of Virtues in Management and the Weak Unity of Virtues in Management}

Extending Wolf's argument to a management context, when managers face a situation and need to decide how to act, they need to see how to be practically wise, how to be just to all the different parties, how to be courageous and generous, and the equivalent for all the virtues that appear to be relevant to the people affected and involved. Being practically wise involves knowing, for instance, whether the value of the money spent on an investment, the associated risks, and other circumstances will lead to an outcome that is worth the money and the risks.

However, whether the outcome is "good" in itself, or to what extent it is better than other possible goals, is a matter of justice, not of practical wisdom. Mother Theresa's idea of helping the extremely poor in India is a matter of justice, generosity, humility, and/or any other moral virtue, not of practical wisdom; how to achieve this goal, in contrast, is a matter of practical wisdom. The first decision to determine what is of worth is not a matter of practical wisdom.

However, going beyond the empirical evidence, there are other types of research that discuss the relative importance of several virtues in terms of specific areas of knowledge. It is important to look into the consequences of the absence of a virtue to see that these consequences are not the same, depending on the combination of virtues, and precisely for this reason, care must be taken regarding which virtue may be crucial at the beginning. This is the case for justice and practical wisdom in management.

Let us take the case of justice and practical wisdom. It could very well be that, in the short run, being practically wise and just in a specific situation is practically impossible, so managers need to establish priorities about which virtue is the one that may be neglected in the short run but that it is possible to attain in the long run.

There is abundant literature showing that the consequences of neglecting specific virtues are not harmless and that the lack of some virtues may produce tough managerial consequences that 
can damage business activity. For instance, this is the case with neglecting justice [51-54], which shows the importance of managing justice and injustice in the workplace $[29,55]$. In addition, there is empirical literature on management showing that the consequences of neglecting specific virtues are different from the consequences of neglecting others. This strictly depends on the different stakeholders involved: practical wisdom is more concerned with the business activity as a whole and so has consequences for the shareholders' wealth, whereas injustice seems to affect the workforce more directly in most situations. Of course, having a demotivated workforce may create many harmful effects on future operations, which in turn would imply a loss of shareholder value.

We have already mentioned that knowledge is a relevant aspect related to virtues. For that reason, we are going to analyze the importance of knowledge and which different types of knowledge are involved in different virtues. We will also analyze which types of knowledge are involved in the process of starting with one virtue while possibly acquiring the rest later.

Wolf has proposed a weak unity of virtues that functions through the knowledge (mainly evaluative) involved in acquiring them [50]. Aristotle argues that each virtue involves knowledge and, specifically, the evaluative knowledge concerned with what is important in terms of that virtue ([1], Book VI). The golden mean (each moral virtue being in the middle of two non-virtuous extremes) implies an element of evaluative knowledge and therefore good judgment, which is a rational element, something that only human beings can possess. This specific knowledge has been given several names (practical wisdom, judgment, rational intelligence, etc.) and is involved in making decisions about things that vary in nature, are unpredictable to a large degree, and require some degree of personal experience. In the case of the law, to be just, it is necessary to follow just laws, but that is not quite enough. People need judgment to make a just decision on a particular application of the law, even if the law is no longer just. Thus, following the rules rigidly will not guide the behavior of a just person, as justice has no virtue that can resist it when a specific and strict policy is followed in all situations. The knowledge that we are interested in - the kind of knowledge that affects virtues-is comparative in nature. It involves two things- "having a sense of how much of one good is worth risking or sacrificing for another, but also understanding when and for what kinds of goods different kinds of action are appropriate" ([50], p. 23). Therefore, "knowledge of the values especially important to the possession of one virtue will thus necessarily involve knowledge of the values important for the possession of the others" ([50], p. 23).

As much of the concern has been attentive to how to make decisions, researchers have placed the focus on practical wisdom and the importance of managers consciously developing this intellectual virtue. Surprisingly enough, when it comes to deciding which objectives should be placed first, practical wisdom seems not to assist managers. Instead, justice seems to be more useful, as justice offers criteria for balancing the objectives at hand. Justifications of which objectives are more critical and which of them are revealed at present, avoidable, need other type of arguments-justice arguments.

Sen distinguishes between 'well-being' and 'agency', the former being the notion that appears in the utility function, and the latter the ability to form goals, commitments and values [56]. In other economic approaches, "maximum utility man" is seen as an "automaton ... with no internal quarrels and no dilemmas" [57]. This model can serve as a tool to decide simple things which require purely preset and well-established knowledge and therefore is not useful for complex and real decisions, as it is the case with managers. However, the practically wise man requires some self-command, with a definition of practical wisdom that includes some "loose, vague, and indeterminate rules" that instruct the practically wise man "to avoid risk" ([57], p. 8). Of course, rules of "practical wisdom" are not categorical imperatives, as there is also the need to balance whether or not they are appropriate to a specific situation. In addition, once he has the knowledge, a prudent man needs to be willing to behave accordingly.

Tiberius and Swartwood explain that "practical wisdom illuminates the nature of a right action, which leads to a focus on the wise person as a perfect judge of what to do" ([48], p. 278). In this definition, practical wisdom also incorporates the knowledge about ends, in which the virtue of justice is necessary. For someone to be considered just, this person must incorporate a specific form of practical 
wisdom, and must look at the different aspects and balance them to decide which one to incorporate when making a decision in order to lead to a good decision. We will examine this more carefully in the next sections of this paper.

There is a crucial component involved in the actions of a wise person, as "the motivation to help others to choose well is implied by the fact that a wise person provides guidance to others and has a concern for others" ([48], p. 283). Thus, this element-motivation to help others-can characterize several virtues rather than practical wisdom alone. As we will see, this element can be seen more clearly when we consider the virtue of justice, which incorporates caring for the results that affect all parties in a decision.

We are interested in managerial decision making, and in the process of acquiring virtues (ideally to achieve most of them) but also in understanding which virtue informs ends and which virtue informs process. Of course, a manager in the way of being wise practices the process of deciding and learns how to become wiser through this process. In the short run, as Sen pointed out, as the end is crucial, a manager should prioritize justice-it seems difficult to be wise and unjust. Afterwards, once the end is there, manager can choose the option with greater practical wisdom. Then, the manager, learning if that option has led to the just outcome or not, can upgrade the learning concerning practical wisdom for future occasions in order to really achieve the desired just end.

If we start being unjust, we lack, from the beginning the necessary wisdom to avoid the consequences of an unjust decision. Therefore, we are unable to avoid unjust consequences in our decisions, which makes us incapable of progressing in the creation of further wisdom or improving our future practical wisdom.

Being completely wise would entail being just and practically wise, but, of course, we should start with distinguishing good (and therefore just) ends from those that are not. This means that, in the short run, we should justify our goals in terms of justice. We should be just from the beginning or, at least, be able to justify why we consider these goals just. This is the minimum wisdom necessary: the short-term wisdom which, according to Sen, helps to start the whole process. Sen considers this minimum wisdom necessary to avoid blatant injustices. Then, from this point on, we can follow paths that can increase practical wisdom and therefore complete the whole virtue set of the manager. Sen points out that it is not possible to attain the ideal world if we do not start from a realistic and not unjust beginning [58]. In this situation, managers are compelled to understand and develop the wisdom initially necessary to avoid the creation of injustice; we add that this initial situation can include the acceptance of not being completely practically wise in the short run. Accepting that we are not completely practically wise and being duty bound to improve the actual situation in which we lack of practically wise virtue is compensated because we avoid the injustice creation that would surely appear to be choosing an unjust end from the beginning and spreading the consequences of this injustice along the way. Thus, wisdom is a long-term goal that involves all virtues, even if not all of them are equally important in the short run. Justice is an end that is worth pursuing, while practical wisdom is a means that drives virtue, allowing us to choose which way to arrive to that desired end. Both can be improved through practice.

Management has mainly investigated two virtues-practical wisdom and justice-precisely because the concept of unity of virtues is not complete but instead is presented in its weak form and is also present in the management profession. Practical wisdom has been studied in strategy [16], in organizational learning [18], and in other fields of management regarding learning and management education [20]. Managers are deemed to need practical wisdom to develop their technical skills, as practical wisdom is seen as the crucial virtue of knowledge. Justice has received attention particularly from the field of organizational justice $[25,26]$, but recently it has also received attention in other areas of research, including management control [27] and social sustainability [31]. From the point of view of individual perceptions, justice is important because people perceive justice in procedures, distributions, managerial treatment, and information disclosure from supervisors. As such, managerial decision making should incorporate these aspects in taking just decisions. If managers do not include these aspects and people perceive injustice, counterproductive behaviors may occur [28]. Therefore, justice is a crucial moral virtue in the management profession [29]. In consequence, we propose the following: 
Proposition 1. Wise management will consistently incorporate justice and practical wisdom in the decision-making process, under the conditions of a weak unity of virtues for management.

\section{Combining Justice and Practical Wisdom to Improve Decision Making. A Framework of Dynamic Evolution for Managerial Decision Making}

In this section, we illustrate the combination of justice and practical wisdom in a decision-making process. We show the combination in Table 1, and we discuss each of the four combinations in the next section, explained in terms of which type of decision making is created. We also go one step further by discussing the dynamics of each decision-making type, distinguishing between the possible ethical development paths that the manager follows, and we show these dynamics and types of management in Table 2. Jointly, Tables 1 and 2 represent four situations that we will discuss in the subsequent section.

Previous literature has shown no consensus about which virtue should be a priority when starting down the path of becoming a wiser manager. Looking at practical wisdom and justice, here we propose that starting with justice makes it easier to end up being practically wise, rather than starting with practical wisdom in order to end up being just. Thus, starting with justice seems reasonable to end up being wiser in a broader sense (as the weak unity of virtues has argued as necessary).

In many traditional frameworks, justice is often seen as a sufficient condition for practical wisdom, but this does not mean that it is also a necessary condition. If this were true, it would mean that a practically unwise decision is always unjust. However, as we will show, that is not necessarily the case. In many situations, a manager can be practically unwise but just in the short run, since companies need to think of strategies for development in the long run, although they may lose money for some period of time. This would be necessary in cases where the company needs people to cooperate today for expected future results.

In contrast, to justify situations in which there is practical wisdom but a lack of justice, it is important to note that injustice, even in the short term, may create situations in which people's attitudes and behaviors could easily go against the organization, and this would harm the organization. In general, and from a managerial point of view, the conventional response has been to consider that, in such situations, managers may put up with unjust decisions that are regarded as the lesser of two evils, asserting that the practical wisdom or effectiveness of the decision justifies the unfairness of the policies applied. In reality, however, people would better understand a just situation even if it may be unwise at some point in the short run. We claim that the time dimension is crucial, and justice has to be the dominant criterion in the short run. The effects of injustice on people are so important that, in the short run, it is better for decision-makers to be practically unwise rather than unjust. In the end, being unjust in the short run would generate injustices that might make it difficult to find practically wise alternatives in the future.

Of course, the ideal situation is to be both practically wise and just, but this may be difficult to achieve. Some decision makers may settle for a decision that is practically wise but unjust, as it may be easier to justify to powerful stakeholders.

We will next examine the framework proposed in Table 1 and the consequences of a decision within the specific combinations of virtues seen in Table 2. We propose a set of hypotheses for each of the four combinations shown in both tables.

Table 1. Combinations of justice and practical wisdom in decision making.

\begin{tabular}{lccc}
\hline \multirow{4}{*}{ Justice } & \multicolumn{2}{c}{ Yes } & No \\
\cline { 2 - 4 } & Yes & $\begin{array}{c}\text { Just, practically wise } \\
\text { decision making }\end{array}$ & $\begin{array}{c}\text { Just, practically unwise } \\
\text { decision making }\end{array}$ \\
\cline { 2 - 4 } & No & $\begin{array}{c}\text { Unjust, practically wise } \\
\text { decision making }\end{array}$ & $\begin{array}{c}\text { Unjust, practically } \\
\text { unwise decision making }\end{array}$ \\
\hline
\end{tabular}


Table 2. Dynamic changes between decision making types— the path of sustainable management.

\begin{tabular}{|c|c|c|c|c|}
\hline & & \multicolumn{3}{|c|}{ Practical Wisdom } \\
\hline \multirow{5}{*}{ Justice } & & \multicolumn{2}{|l|}{ Yes } & No \\
\hline & Yes & $\begin{array}{c}\text { Wise } \\
\text { management }\end{array}$ & 1 & $\begin{array}{c}\text { Sustainable wise } \\
\text { management }\end{array}$ \\
\hline & & $2^{\prime}$ & & $1^{\prime}$ \\
\hline & No & Unsustainable & 2 & Unwise \\
\hline & & wise managemen & & Management \\
\hline
\end{tabular}

* Strictly speaking, we should call this 'weak wise management'. We consider our concept of wise management to be built into the concept of the 'weak' unity of virtues we have discussed in previous sections of this paper.

\subsection{Just, Practically Wise Decision Making—Wise Management}

This is an ideal situation in which the two virtues (practical wisdom and justice) are present, the manager enters into a virtuous cycle of ethical development that allows him or her to become a wise manager, and the organization develops virtuousness [33]. When a specific situation needs to be resolved, managers should try to find an alternative of action that includes both virtues. Thereby, just objectives are chosen and, to attain them, practically wise paths are taken. It is clear that, in the presence of justice and practical wisdom, it is possible and more probable for people to flourish within the organizational context [1,2]. Virtues understood in this way may be interesting because the organizational context makes it worthwhile to use a framework in which the two virtues that are chosen-justice and practical wisdom—are the ones worth pursuing [3]. People's evaluative judgments are then based on the facts or specific results they see after some decision affects them, which implies that people will start learning about the practical wisdom and justice that the management displays. Therefore, new facts that come out of a decision may improve this particular and situational learning. Thus, as managerial decision making affects people positively, being affected by positive perceived outputs reinforces their learning in the virtuous direction over time [4]. People and managers are then consistently learning from each interaction and decision, and the situation improves over time, as both help each other to become more virtuous. Individuals' moral approach to justice regarding 'what should be' is consistent with the perceptions of 'what actually happens', and, therefore, this match of expectations and facts helps to improve virtuous learning over time [5]. Each specific interaction within a given organization may allow managers to choose the specific paths that guarantee the achievement of justice objectives from a person-centric perspective of moral development $[7,8]$ while, at the same time, balancing those variables that are deemed crucial in a specific context, following a person-situational perspective [10-14]. Also, this situation of virtuous acquisition and reinforcement tends to be present in personal and professional spheres, which makes this reinforcement even stronger [6]. Therefore, we propose the following proposition:

Proposition 2. Just and practically wise decision making is a stable situation in which a state of wise management is acquired that tends to continue over time.

\subsection{Just and Practically Unwise Decision Making—Sustainable Wise Management}

This possibility offers a potential virtuous cycle, as it may help managers to balance the ends in a given organization and choose the ones that are just and therefore morally right. This case allows for better involvement and avoids bad consequences of injustice, which in turn helps managers to improve practical wisdom in the future [28].

The desire to maintain justice 'pushes' managers to understand better means-ends relationships to achieve it, and this develops practical wisdom in order to achieve the desired just ends [1]. This 
situation, then, can be considered sustainable wise management, since it evolves in the direction of learning around practical wisdom. This promotes the managerial improvement of the general wisdom of the manager (acquiring a weak unity of virtues with both justice and practical wisdom). Sustainability research has found that justice is one of the crucial variables in generating sustainable models of human resource management [31]. In that sense, once just objectives are set up, people tend to commit to the organization and generate behaviors that help organizations to become more sustainable over time. In turn, this may increase potential courses of action that are more practically wise in the long run.

The dynamics of sustainable wise management, as shown in Table 2, follow an evolution toward wise management by following path 1 . This involves learning how to maintain justice and generate practical wisdom as a result, which transforms sustainable wise management into wise management. Of course, it might happen that the learning process turns out to be negative, although this situation seems scarcely possible (discontinuous path 1 ' to transform sustainable wise management into unwise management). However, research has found that having the right (just) moral objectives helps managers to improve their practical wisdom skills [59]. Therefore, once just objectives are set up, they tend to improve the wisdom of managers through the acquisition of the intellectual virtue of practical wisdom, thus increasing the knowledge associated therewith. Therefore, we propose the following propositions:

Proposition 3. Just and practically unwise decision making is an unstable situation in which sustainable wise management is practiced.

Proposition 4. Sustainable wise management tends to evolve over time and arrive at a state of wise management through acquiring practical wisdom.

\subsection{Unjust, Practically Wise Decision Making_Unsustainable Wise Management}

This possibility offers a potential vicious cycle, as it may worsen management decision making over time. Even if managers propose decisions that hold from a virtue knowledge perspective, the ends are wrong and unjust and may have negative consequences in the short run, being very negative and difficult to uphold $[12,28,60]$.

From the beginning, unsustainable wise management chooses 'technically wise' courses of action without taking into account the (morally) right end, which is the just one. This may have consequences counter to the maintenance and development of practical wisdom in the future, and in general, the manager becomes less wise. This is closely related to the concept of negative learning as elaborated in Rosanas [61]. Once unjust consequences are generated, managers have incentives to continue generating unjust consequences, since it is difficult to change decisions if first the unjust consequences are not compensated for. Thus, as a consequence, people's perceptions will worsen if the consequences of previous injustices are not first compensated appropriately [62]. Then, managers will tend to continue generating paths that lead to unjust objectives. In the end, this cannot be changed easily, so practically unwise paths will more likely be chosen.

The dynamics of unsustainable wise management, as shown in Table 2, follow Path 2 and transform into a state of Unwise Management as a consequence of not pursuing the right and just objectives. In general, having the wrong objectives prevents managers from attaining virtues and leads them to continue generating injustice, which may push them more easily toward finally becoming practically unwise. Notice that, in contrast, we argue that Path 2 will seldom be taken because unjust ends always benefit some of the parties involved (some powerful stakeholders), and these parties will not be anxious to change the end. Injustice may generate counterproductive behaviors [28], and managers will need more managerial justice precisely at times when they have demonstrated from the beginning that they lack the minimum of setting up just objectives [29]. Therefore, it is not impossible to improve wisdom at this point, but it becomes more challenging when unjust consequences have 
been generated and managers first need to correct injustices before choosing the right objectives, which they have previously failed to do [63]. Additional justice dimensions are more difficult to promote, and injustice can therefore easily increase over time [30]. We thus propose the following propositions:

Proposition 5. Unjust and practically wise decision making is an unstable situation in which unsustainable wise management is practiced.

Proposition 6. Unsustainable wise management tends to evolve over time and arrive at a state of unwise management through worsening injustices and a loss of practical wisdom.

\subsection{Unjust, Practically Unwise Decision Making—Unwise Management}

This case is the worst case, but it is by no means impossible. There are vicious circles in which managers have not chosen the appropriate just objective and reinforce their strategy by creating injustice that continues and increases [29,32]. Incentives to improve the situation usually do not exist, as systems tend to continue along the lines of what was initially set up. Therefore, people pursue the incentives in the current system, even if they are aware that those incentives are not leading to the desired crucial goals. They may even be aware that those incentives will create undesired consequences that will become worse and worse over time [27].

In this possibility, the choice is practically unwise, and the objective that is reinforced is unjust, and this tends to become worse over time. The consequences of injustice may start from the beginning $[12,28,60]$, and no awareness of the consequences, possible solutions, or incentives to choose practically wise courses of action will emerge [59]. Therefore, we propose the following proposition:

Proposition 7. Unjust and practically unwise decision making is a stable situation in which a state of unwise management is acquired, which tends to continue over time.

\section{An Application of This Analysis to Four Real-World Cases}

To make the framework presented applicable and to better understand how it works in real organizations, we offer the following four cases, one for each of the quadrants in Tables 1 and 2. We offer a case to illustrate wise management, considered to be management with a weak unity of virtues (decision making that is just and practically wise). In general, in this type of decision making, organizational stakeholders consistently support the decision making practiced within the organization, and the results of the daily decisions tend to generate a situation that allows wise management to continue over time. We also present a case of sustainable wise management which illustrates how decisions that incorporate justice and are not always practically wise. This type of decision making is associated with the good consequences of creating justice and avoiding injustice while also potentially increasing practically wise decision making options over time. Therefore, managers tend toward improving decision making, and businesses can evolve over time and become organizations that practice wise management. The third case presents a situation of unsustainable wise management, in which decisions generate injustice but are practically wise; we therefore show how stakeholders react against the injustices thus created and ask for compensation. In turn, this worsens practically wise options, so the dynamics tend to evolve toward unwise management. Finally, we offer a fourth case to illustrate unwise management in which decision making is unjust and practically unwise. The situation is therefore stable and tends to worsen over time, so it is difficult for the company to generate a different type of decision making which might eventually shift the situation towards potential improvement. 


\subsection{A Case with Just, Practically Wise Decision Making_Wise Management}

It is not easy to pick just one example of a firm managed with practical wisdom and justice because there are so many. One example of a specific firm seems particularly appropriate because it has become a classic, and its founder also passed away very recently: an airline which, even in difficult times, has succeeded not only in surviving without losses, but also in growing and providing better service. Southwest Airlines was founded in 1971 with the idea of providing better service (mainly, arriving on time) at a lower cost, with a spirit that was clearly expressed in the company's mission statement: "The mission of Southwest Airlines is dedication to the highest quality of Customer Service delivered with a sense of warmth, friendliness, individual pride, and Company Spirit. We are committed to provide our Employees a stable work environment with equal opportunity for learning and personal growth." (https://www.southwest.com/html/about-southwest/index.html).

Herb Kelleher and Colleen Barret (his secretary and successor as CEO) undoubtedly wanted to create an organization where decision making took place in a way that was just and practically wise. Contrary to widely held beliefs, they succeeded in achieving profitability for an airline that, in the beginning, was very small, had considerable legal limitations, and had to stay true to its vision to make it possible. At the same time, they set out to be just with their employees, with their customers, and, as a consequence, with their shareholders. They succeeded, and in a stable way: the company has maintained the same spirit while growing to incredible proportions, with satisfied customers, satisfied employees and satisfied shareholders.

The internal fairness (justice as perceived by the employees) of the organization was clearly shown in a well-known case (Stanford case HR-1A): in 1993, they had 98,000 applicants, 16,000 of whom were interviewed and 2700 hired, many of them willing to accept lower salaries than they were enjoying at the company where they were working when they sent in their applications.

\subsection{A Case with Just and Practically Unwise Decision Making-Sustainable Wise Management}

This is the case of Picadillo Brothers, a European firm in a highly seasonal business related to different activities in sport and leisure. The company was successful and was considered to be highly competitive. The main reasons for its success were excellent facilities, with the latest technology and first-rate customer service. A crucial factor in the firm's success was an excellent management team, mainly in operations. The head of operations was a highly technical competent person with very good human qualities.

The seasonal business of the company, however, kept profitability lower than management and the stockholders would have wished. Even though it had expanded and increased revenues and profits in the preceding years, management considered the seasonal nature of the business to be a problem. They had very good people, but the firm either had to pay them for the whole year, with practically no work in the low season, or risk losing them by letting them go at the end of the high season. One idea seemed worth exploring: starting a similar business in the Southern Hemisphere. The first option was to send people there from the primary business, paying them more to be incentivized. This, however, seemed an unfair option, as the operations manager and many of the employees pointed out in a verbal communication with the authors:

"First, they will take some of my best people here and send them there. Second, those people will make much more money than the ones here; and third, we are subsidizing them and this is going to be argued as a reason not to increase salaries substantially here, when our people are doing a very good job and making a lot of profit and the money they generate here is used to pay their whimsical venture there!"

So, it seemed this option of sending people from the north and paying them more was not fair. Then, they tried to find alternatives, starting with delaying the investment, even if this was considered practically unwise. In doing so, Picadillo should have set up fair objectives for all stakeholders involved. The company should have assumed that the workers, as the primary group of interest should be 
involved, as this is a requirement of justice, even if it meant delaying the investment which is, as we have said, was practically unwise.

If the managers were practicing sustainable wise management, the decision should have been to set up the Southern activities as a new and separate company. The new subsidiary might show losses, which would not be made up by the Northern branch, and the new venture could go bust. If this happened, there would be immediate pressure for a change, which could take place in two different directions: toward a state of wise management (Table 2, Path 1) or toward a state of unwise management (Table 2, Path 1'). We claim that the first possibility is more likely than the second. If management really believes that the investment in the subsidiary is "good," they can raise capital from shareholders (the ones that are more interested in investing), use it to develop the Southern activities, and keep the current profits in the North. This could allow the firm to increase salaries in the North, if this is just, and evaluate managers based on their actual performance with no interference from what happens in the South.

\subsection{A Case with Unjust, Practically Wise Decision Making_Unsustainable Wise Management}

There are also many examples today of unjust but practically wise management. Many firms start with the idea of exploiting employees. One delivery company, for instance, was created by a young engineer who produced a computer system to manage a team of people who are tasked with going to purchase/pick up things that the customer desires and deliver them quickly for a very low price. On paper, the people who work under this system can accept the specific jobs they want. However, if they refuse a job, they may not be hired again. Their pay is very low, and the company operates at a loss, but the value of the company has kept increasing from the beginning and it is often cited as a success story. Nonetheless, the truth is that the company has engaged in doubtfully legal practices from the point of view of labour laws and has recognized that hiring its delivery people as regular workers, and thus paying social security taxes and so on, would make the company unsustainable. The decision to start this firm was made with practical wisdom in an unjust way, which follows the quadrant of Table 2 that concerns an unsustainable wise management.

Although we need to know the exact alternative courses of action in order to evaluate practical wisdom, from the shareholders' perspective it can be argued that the decision to create the firm was made with practical wisdom. They started a business with high demand, chose the right kind of people, and, possibly, came up with a firm that, in the long run, could become profitable. However, they started from a situation that was unjust and perceived as unfair by the people who carried out the actual delivery of the goods. They could see that people in management positions were making good salaries, while they had to accept very low pay simply because they were unemployed, and their alternative was earning nothing.

The situation can possibly evolve in two different directions, as shown in Table 2-toward unwise management (Path 2) or toward wise management (Path 2'). The first one is more likely to happen, because there are no short-term pressures to change from the stockholders or from management. Even if the effects of injustice are suffered in the short run, typically they will be difficult to compensate and will only show for all the stakeholders in the long-run. In contrast, the effects of having practical wisdom will show in the very short run, perhaps even in this year's numbers, and therefore, there is pressure to continue the current course of action. In general, this would lead to offering the same service in other cities, which would probably perpetuate the unjust situation. Therefore, the situation is unsustainable in the long run in terms of HRM policies and their future consequences. It could easily become an unwise type of management because the courses of practically wise action would be more difficult in the future if the consequences of the injustice created were compensated. In the end, the business model might even be at stake, since future profits could be more difficult to generate. 


\subsection{A Case with Unjust-Practically Unwise Decision Making_Unwise Management}

In the years before the Great Recession, it was rather common for banks to have a system of incentives based on the total credits conceded by the bank, no matter how good they were. This would affect the KPIs of the management team as long as it was not discovered that the loans were bad. That is what Bank Nine did. It was unwise, of course, because it encouraged employees to give bad loans, but this did not show in the financial statements in the short run. It became obvious only once the Recession hit. Many loans defaulted, and many of the banks of this kind simply went bankrupt. Besides, it was unjust to the employees and customers: first, because employees lost their jobs and many customers went bankrupt as well. But the management team kept the generous bonuses they obtained during the good years. Employees were not considered as part of the company, as people with their own motives and aspirations, and without the requirements of justice that are necessary when decisions affect them. People were considered means to achieve ends, purportedly for the company as a whole, even at the expense of the company's survival. The decisions made were practically unwise and unfair, with the wrong incentives for employees. Only a few people were making undeserved amounts of money at the expense of the future of the company and the potential earnings of the employees. Therefore, the situation in many banking companies ended up with scandals that led the banks to bankruptcy. In this case, top management put forward huge incentives to make employees sell mortgages to people at a very high risk and also send high risk products to savers who were not aware of the risk of losing their life savings. Decision making was not just for these customers, for employees who received incentives to do the wrong thing for the company, for the owners of the bank, or for society as a whole. Obviously, the decisions made were not practically wise, as they incorporated huge risks and put the company at stake. In the end, the bank went bankrupt, so the company ended up ceasing activities.

\subsection{Sustainable Wise Management versus Unsustainable Wise Management}

To recapitulate, the two intermediate cases (unsustainable wise management and sustainable wise management) are the most interesting ones. We might take a second look at the case presented for sustainable wise management and see what happens if management decided on a practically wise but unjust alternative. Of course, the alternative of not investing in the subsidiary may be practically unwise, given the management's assessment of the firm's future prospects, but then, if it creates fairness, it will more likely generate practically wise alternatives for the future. We might imagine the same case following a decision to invest but, in doing so, creating injustices amongst employees, with the subsidiary receiving better treatment as an organizational unit than the parent organization. The situation would then be likely to remain stable. The only pressure for change would come in the future from the employees who would feel they were being treated unfairly-some might even leave the firm, creating a situation that would no doubt become practically unwise (the best employees would be able to find better jobs most easily).

We then submit that choosing the option of "just, practically unwise decision making" seems the most reasonable one, as it forces managers to search actively for a solution. In the case of one of the "unjust, practically wise decision making" options, in contrast, there is no pressure for managers to find another solution, since only future complaints would put the company's sustainability into question, but the short run is not at stake. Therefore, it seems that, in the case of Picadillo Brothers, the managers chose the sustainable option. For the delivery company, however, choosing the unsustainable option resulted in unwise management. Only a just organization can be an organization where people are motivated by the organizational objectives. Thus, it may become an organization that has results that are above normal (perhaps only in the long run). The current emphasis on "strategy design" [64] in management courses misses that point. What we have attempted to do in this paper is to show that a necessary condition for this to happen is that justice be emphasized from the beginning as the right end to pursue. Moreover, this will help to develop other virtues (including practical wisdom as a crucial element of situational knowledge that is necessary to be developed over time) and create an even better organizational climate. 
For the case of the delivery company, the situation would (unfortunately) be stable in the short run, and, as we have pointed out, the only pressure to change anything would be from employees who think they are being treated unfairly. The ones that are better or have other options would leave the firm. In the end, the company would be worse off, and then the situation would become practically unwise.

\section{Results and Managerial Implications}

It is interesting, at this point, to present the managerial implications of our analysis. We have analyzed four possible situations that can be found in practice, both conceptually and through an example. First, the ideal possibility of wise management (first quadrant) -if an organization is in that type of situation, we have argued that it is a stable one, where one can remain indefinitely. This does not mean, however, that it is possible to remain in this state by doing nothing; it simply means that you have to continue to pursue justice and practical wisdom at the same time.

Our fourth quadrant is unwise management, where management does not have any of the two virtues. This is also a "stable" situation, in the sense that it is very difficult to get out of it: more likely, the organization will disappear in due time, unless an extraordinary effort can be made to change the starting point. Unfortunately, you cannot acquire justice and practical wisdom overnight.

The two intermediate possibilities (quadrants 2 and 3) are the really interesting ones from a managerial point of view. In fact, in some practical situations, management may be able to choose between what we have called unsustainable wise management and sustainable wise management. The latter (as the name suggests) is preferable, because it permits evolving toward wise management, as we have explained above.

The case of Picadillo Brothers that we used to discuss the possibility of sustainable wise management may illustrate this choice as well. In fact, the way the new Southern investment actually started for Picadillo Brothers, almost as the natural thing to do, was a case of unsustainable wise management: unjust high salaries for people in the South and low salaries for people in the North, who were the ones making money for the company through their good performance,.

Management soon realized that this was a dangerous path, because it was creating a bad organizational climate in the North and, at the same time, more and more money was going into investments in the South. They changed the situation to a "practically unwise, but just" one. Strong pressure to do things better was exerted in the South, which finally succeeded in becoming very profitable without creating problems in the North, thus shifting (as our analysis predicted) towards a situation of wise management. Thus, justice is more important to start a process of virtue development than practical wisdom, if we are faced with choosing between them.

\section{Summary and Conclusions}

In this paper, we first presented and analyzed the concept of a weak unity of virtues, under the assumption that practical wisdom and justice are the two main virtues that should be developed in management. Then, as our main finding, we argued that practical wisdom, the currently non-forgotten virtue, does not need to be the starting point for a virtuous environment in organizations, and it may not help managers make the right choices. Justice, in a wider sense, is the best starting point for a dynamic process aimed at creating virtuous management, and, as a consequence, wiser and wiser management where justice has to take the driver's seat. If a manager focuses on practical wisdom while allowing injustice to exist in the short term, in the end, the manager is likely to fail to improve future practical wisdom, therefore resulting in unsustainable wise management. In that case, practical wisdom, as the main intellectual virtue, may become short-sighted without justice guiding it. As a result, the usual consequences of the decisions are forgotten in terms of a more crucial element-the injustice generated for the recipients which, in turn, has effects on the organization's long-term effectiveness and efficiency.

In contrast, if a manager focuses on justice in the short term by incorporating the necessary practical wisdom, sustainable wise management is practiced, and even if some practically unwise 
decisions are generated, the manager can avoid unfair consequences in the short run, which allows for the further improvement of future practical wisdom.

Being a practically wise manager but unjust is not sustainable, sometimes not even in the short term, while it is possible to be practically unwise and just in the short term, allowing for some practically unwise decisions for the sake of justice, and acquiring general wisdom as a manager along the way. This is so because, by doing this, the manager gains a deeper understanding of the consequences of decisions and achieves a state of wisdom in which justice is the guiding moral principle. At the same time, this helps to improve practical wisdom, as the manager needs to look for better decisions without creating any injustice, even in the short term.

We have examined the four quadrants that come out of the four combinations of justice and practical wisdom and developed propositions for each quadrant. Propositions are developed for each decision-making type depending on whether the manager takes into account justice or not and practical wisdom or not. We showed how there are two types of management that are stable-wise management (with justice and practical wisdom) and unwise management (without justice and without practical wisdom). There are also two interesting intermediate situations-sustainable wise management and unsustainable wise management, the first tending to evolve towards wise management and the second towards unwise management. This was then applied to four real-world situations.

Our contribution is the building of a conceptual framework in which justice is shown to be a better starting point for achieving other virtues, because it allows decision-makers to be wiser, since just objectives help to find practically wiser ways of attaining them. We show that, when, in the short run, there is no practical wisdom but there is justice, this practical wisdom is easily attained in the end. By entering a virtue-generating circle, managing with justice from the beginning as a guiding principle, it becomes easier to achieve practical wisdom. The organization then develops in a way that is desirable and, at the same time, it is likely to produce better results in the future that incorporate justice and practical wisdom.

Our use of the weak unity of virtues in this paper includes only justice and practical wisdom, but we believe this reasoning can also be extended to other virtues that are important in organizations. We have chosen to start with these two, as both have been studied extensively in decision making and management. With those virtues in mind, managers can approach a wide range of managerial situations and decide according to the two most important virtue-related criteria that managers need to consider.

Author Contributions: Conceptualization, N.C.-E. and J.M.R.; Writing—original draft, N.C.-E. All authors have read and agreed to the published version of the manuscript.

Funding: This research received no external funding.

Conflicts of Interest: The authors declare no conflict of interest.

\section{References}

1. Aristotle. The Nicomachean Ethics; Translated by W.D. Ross, Revised by Brown, L.; Oxford University Press: Oxford, UK, 2009.

2. Pieper, J. Justicia y Fortaleza; Ediciones Rialp: Madrid, Spain, 1972.

3. Nussbaum, M.C. Virtue Ethics: A Misleading Category? J. Ethic 1999, 3, 163-201. [CrossRef]

4. Appiah, K.A. More Experiments in Ethics. Neuroethics 2010, 3, 233-242. [CrossRef]

5. Cugueró-Escofet, N.; Fortin, M. One Justice or Two? A Model of Reconciliation of Normative Justice Theories and Empirical Research on Organizational Justice. J. Bus. Ethics 2014, 124, 435-451.

6. Cheney, G.; Lair, D.J.; Ritz, D.; Kendall, B.E. Just a Job?: Communication, Ethics, and Professional Life; Oxford University Press: New York, NY, USA, 2009.

7. Schwartz, M.S. Ethical Decision-Making Theory: An Integrated Approach. J. Bus. Ethics 2016, 139, 755-776. [CrossRef]

8. Torres, M.B. Character and Decision Making. Ph.D. Thesis, University of Navarra, Pamplona, Spain, 2001.

9. Rest, J. Development in Judging Moral Issues; University of Minnesota Press: Minneapolis, MN, USA, 1979. 
10. Treviño, L.K. Ethical decision making in organizations: A person-situation interactionist model. Acad. Manag. Rev. 1986, 11, 601-617. [CrossRef]

11. Treviño, L.K.; Butterfield, K.D.; McCabe, D.L. The Ethical Context in Organizations: Influences on Employee Attitudes and Behaviors. Bus. Ethics Q. 1998, 8, 447-476. [CrossRef]

12. Treviño, L.K.; Weaver, G.R. Organizational Justice and Ethics Program 'Follow-Through': Influences on Employees' Harmful and Helpful Behavior. Bus. Ethics Q. 2001, 11, 651-671. [CrossRef]

13. Treviño, L.K.; Weaver, G.R.; Gibson, D.G.; Toffler, B.L. Managing Ethics and Legal Compliance: What Works and What Hurts. Calif. Manag. Rev. 1999, 41, 131-151. [CrossRef]

14. Treviño, L.K.; Weaver, G.R.; Reynolds, S.J. Behavioral Ethics in Organizations: A Review. J. Manag. 2006, 32, 951-990. [CrossRef]

15. Bachmann, C.; Habisch, A.; Dierksmeier, C. Practical Wisdom: Management's No Longer Forgotten Virtue. J. Bus. Ethics 2018, 153, 147-165. [CrossRef]

16. Tsoukas, H. Strategy and virtue: Developing Strategy-as-Practice Virtue Ethics. Strateg. Organ. 2018, 16, 323-351. [CrossRef]

17. Billsberry, J.; Birnik, A. Management as a Contextual Practice: The Need to Blend Science, Skills and Practical Wisdom. Organ. Manag. J. 2010, 7, 171-178. [CrossRef]

18. Mackay, D.; Zundel, M.; Alkirwi, M. Exploring the Practical Wisdom of Mētis for Management Learning. Manag. Learn. 2014, 45, 418-436. [CrossRef]

19. Rooney, D. Practical Wisdom: The Right Way to Do the Right Thing by Schwartz B. and Sharpe K. E., 2010. New York: Riverhead Books. Acad. Manag. Learn. Educ. 2013, 12, 320-321. [CrossRef]

20. Antonacopoulou, E. Making the Business School More 'Critical': Reflexive Critique Based on Phronēsis as a Foundation for Impact. Br. J. Manag. 2010, 21, 6-25. [CrossRef]

21. Hurst, D.K. Is Management Due for a Renaissance? Harv. Bus. Rev. 2014, $2-4$.

22. Cameron, K.S.; Bright, D.; Caza, A. Exploring the Relationship between Organizational Virtuousness and Performance. Am. Behav. Sci. 2004, 47, 766-790. [CrossRef]

23. Eisenberg, E.M. Jamming: Transcendence through Organizing. Commun. Res. 1990, 17, 139-164. [CrossRef]

24. Nussbaum, M.C. The Therapy of Desire: Theory and Practice in Hellenistic Ethics; Princeton University Press: Princeton, NJ, USA, 1994.

25. Greenberg, J. Organizational Justice: Yesterday, Today, and Tomorrow. J. Manag. 1990, 16, 399-432. [CrossRef]

26. Colquitt, J.A.; Greenberg, J.; Zapata-Phelan, C.P. What is Organizational Justice? A Historical Overview. In Handbook of Organizational Justice; Greenberg, J., Colquitt, J.A., Eds.; Lawrence Erlbaum: Mahwah, NJ, USA, 2005.

27. Cugueró-Escofet, N.; Rosanas, J.M. The Ethics of Metrics: Overcoming the Dysfunctional Effects of Performance Measurements Through Justice. J. Bus. Ethics 2017, 140, 615-631. [CrossRef]

28. Conlon, D.E.; Meyer, C.J.; Nowakowski, J.M. How Does Organizational Justice Affect Performance, Withdrawal and Counterproductive Behaviour? In Handbook of Organizational Justice; Greenberg, J., Colquitt, J.A., Eds.; Lawrence Erlbaum: Mahwah, NJ, USA, 2005.

29. Cropanzano, R.; Bowen, D.E.; Gilliland, S.W. The Management of Organizational Justice. Acad. Manag. Perspect. 2007, 21, 34-48. [CrossRef]

30. Fortin, M.; Cropanzano, R.; Cugueró-Escofet, N.; Nadisic, T.; Hunter, P. How Do People Judge Fairness in Supervisor and Peer Relationships? A reassessment of the dimensions of justice. Hum. Relat. 2019. [CrossRef]

31. Cugueró-Escofet, N.; Ficapal-Cusí, P.; Torrent-Sellens, J. Sustainable Human Resource Management: How to Create a Knowledge Sharing Behaviour through Organizational Justice, Organizational Support, Satisfaction and Commitment. Sustainability 2019, 11, 5419. [CrossRef]

32. Cugueró-Escofet, N.; Rosanas, J.M. The Just Design and Use of Management Control Systems as Requirements for Goal Congruence. Manag. Account. Res. 2013, 24, 23-40. [CrossRef]

33. Cameron, K.S.; Winn, B. Virtuousness in Organizations. In The Oxford Handbook of Positive Organizational Scholarship; Cameron, K.S., Spreitzer, G.M., Eds.; Oxford University Press: New York, NY, USA, 2012; pp. 231-243.

34. Ghoshal, S. Bad Management Theories are Destroying Good Management Practices. Acad. Manag. Learn. Educ. 2005, 4, 75-91. [CrossRef] 
35. Jensen, M. Value Maximization, Stakeholder Theory and the Corporate Objective Function. J. Appl. Corp. Financ. 2001, 4, 8-21. [CrossRef]

36. Pfeffer, J. Leadership BS; Harper Business: New York, NY, USA, 2015.

37. Bower, J.L.; Lynn, S.P. The Error at the Heart of Corporate Leadership: Most CEOs and Boards Believe that Their Main Duty Is to Maximize Shareholder Value. It's Not. Harv. Bus. Rev. 2017, 95, 50-59.

38. Erhard, W.; Jensen, M.C.; Zaffron, S. Integrity: A Positive Model that Incorporates the Normative Phenomena of Morality, Ethics, and Legality_Abridged (English Language Version). Harvard Business School NOM Unit Working Paper No. 10-061; Barbados Group Working Paper No. 10-01; Simon School Working Paper No. 10-07. Available online: https://ssrn.com/abstract=1542759 (accessed on 29 January 2020).

39. Roca, E. Introducing Practical Wisdom in Business Schools. J. Bus. Ethics 2007, 82, 607-620. [CrossRef]

40. Goldman, B.M.; Cropanzano, R. "Justice" and "Fairness" Are Not the Same Thing. J. Organ. Behav. 2015, 36, 313-318. [CrossRef]

41. Folger, R. Fairness as a Moral Virtue. In Managerial Ethics: Moral Management of People and Processes; Schminke, M., Ed.; Lawrence Erlbaum: Mahwah, NJ, USA, 1998.

42. Cugueró-Escofet, N.; Rosanas, J.M. Social Dynamics of Justice: The Ex-ante and Ex-post Justice Interplay with Formal and Informal Elements of Management Control Systems. In Social Dynamics of Organizational Justice; Stephen, W.G., Steiner, D.D., Skarlicki, D.P., Eds.; Information Age Publishing: Charlotte, NC, USA, 2015.

43. Cropanzano, R.; Ambrose, M.L. Procedural and Distributive Justice Are More Similar than You Think: A Monistic Perspective and a Research Agenda. In Advances in Organizational Justice; Greenberg, J., Cropanzano, R., Eds.; Stanford University Press: Stanford, CA, USA, 2001; pp. 119-151.

44. Kulik, C.T.; Cropanzano, R. Justice in the Workplace: From Theory to Practice, Vol. 2. Adm. Sci. Q. 2001, 46, 785. [CrossRef]

45. Folger, R.; Cropanzano, R. Organizational Justice and Human Resource Management; Sage: Beverly Hills, CA, USA, 1998.

46. Thurston, P.W.; McNall, L. Justice Perceptions of Performance Appraisal Practices. J. Manag. Psychol. 2010, 25, 201-228. [CrossRef]

47. Cugueró-Escofet, N.; Rosanas, J.M. Justice: A Sufficient Condition for Goal Congruence in Management Control Systems. Eur. Account. Manag. Rev. 2015, 2, 104-122. [CrossRef]

48. Tiberius, V.; Swartwood, J. Wisdom Revisited: A Case Study in Normative Theorizing. Philos. Explor. 2011, 14, 277-295. [CrossRef]

49. Beabout, G.R. Management as a Domain-Relative Practice that Requires and Develops Practical Wisdom. Bus. Ethics Q. 2012, 22, 405-432. [CrossRef]

50. Wolf, S. Moral Psychology and the Unity of the Virtues. Ratio 2007, 20, 145-167. [CrossRef]

51. Gilliland, S.W.; Steiner, D.D.; Skarlicki, D.P. Emerging Perspectives on Managing Organizational Justice; IAP: Greenwich, CT, USA, 2002.

52. Tepper, B.J. Health Consequences of Organizational Injustice: Tests of Main and Interactive Effects. Organ. Behav. Hum. Decis. Process. 2001, 86, 197-215. [CrossRef]

53. Martin, J. Inequality, Distributive Injustice, and Organizational Illegitimacy. In Social Psychology in Organizations_Advances in Theory and Research; Murnighan, J.K., Ed.; Prentice Hall: Englewood Cliffs, NJ, USA, 1993; pp. 296-321.

54. Bies, R.J.; Tripp, T.M. The Use and Abuse of Power: Justice as Social Control. In Organizational Politics, Justice, and Support: Managing the Social Climate of Work Organizations; Cropanzano, R., Kacmar, M.K., Eds.; Quorum Books: New York, NY, USA, 1995; pp. 131-145.

55. Reb, J.; Goldman, B.M.; Kray, L.J.; Cropanzano, R. Different Wrongs, Different Remedies? Reactions to Organizational Remedies after Procedural and Interactional Injustice. Pers. Psychol. 2006, 59, 31-64. [CrossRef]

56. Sen, A. On Ethics and Economics; Blackwell: Oxford, UK, 1987.

57. Lipka, D. The Max U Approach: Prudence Only, or Not Even Prudence? A Smithian Perspective. Econ. J. Watch 2013, 10, 2-14.

58. Sen, A. The Idea of Justice. Analysis 2009, 71, 204-207.

59. Rosanas, J.M.; Velilla, M. The Ethics of Management Control Systems: Developing Technical and Moral Values. J. Bus. Ethic 2005, 57, 83-96. [CrossRef] 
60. Rupp, D.E.; Spencer, S. When Customers Lash Out: The Effects of Customer Interactional Injustice on Emotional Labor and the Mediating Role of Discrete Emotions. J. Appl. Psychol. 2006, 91, 971-978. [CrossRef] [PubMed]

61. Rosanas, J.M. Decision-Making in an Organizational Context: Beyond Economic Criteria; Palgrave Macmillan: England, UK, 2013.

62. Cugueró-Escofet, N.; Fortin, M.; Canela, M.-A. Righting the Wrong for Third Parties-How Monetary Compensation, Procedure Changes and Apologies Can Restore Justice for Observers of Injustice. J. Bus. Ethics 2014, 122, 253-268. [CrossRef]

63. Okimoto, T.G.; Tyler, T.R. Is Compensation Enough? Relational Concerns in Responding to Unintended Inequity. Group Process. Intergroup Relat. 2007, 10, 399-420. [CrossRef]

64. Bower, J.L. The Teaching of Strategy: From General Manager to Analyst and Back Again? J. Manag. Inq. 2008, 17, 269-275. [CrossRef]

(C) 2020 by the authors. Licensee MDPI, Basel, Switzerland. This article is an open access article distributed under the terms and conditions of the Creative Commons Attribution (CC BY) license (http://creativecommons.org/licenses/by/4.0/). 